\title{
Attitudes of young Czechs towards immigration: comparison of 2011 and 2016
}

\author{
Lenka Pavelková*, Martin Hanus, Jiří Hasman
}

Charles University, Faculty of Science, Department of Social Geography and Regional Development, Czechia

* Corresponding author: lenka.pavelkova@natur.cuni.cz

\begin{abstract}
The paper aims to analyse the attitudes towards immigration among Czech youth and their changes on two distinct surveys of young Czechs (aged 14-19) held in 2011 and 2016, the years before and after a period of a greatly increased inflow of migrants to the European Union. In these surveys, special focus was given to changes in attitudes and factors influencing attitudes in each year. The results show that there was not a big difference in attitudes between both samples. Nevertheless, looking closely at the results, we found two main differences. The first was higher polarisation of answers in survey from 2016 than from the one held in 2011. The second one was in factors influencing answers, mainly in the statement on having an immigrant among close friends.
\end{abstract}

\section{KEYWORDS}

attitudes towards immigration; Czechia; immigration; secondary schools

Received: 21 October 2019

Accepted: 11 March 2020

Published online: 10 April 2020

Pavelková, L., Hanus, M., Hasman, J. (2020): Attitudes of young Czechs towards immigration: comparison of 2011 and 2016.

AUC Geographica 55(1), 27-37

https://doi.org/10.14712/23361980.2020.5

(C) 2020 The Authors. This is an open-access article distributed under the terms of the Creative Commons Attribution License (http://creativecommons.org/licenses/by/4.0). 


\section{Introduction}

In the years 2015 and 2016, the European Union (EU) experienced a highly increased inflow of migrants, mainly refugees from the Middle East and Africa. The increase in the number of asylum applications in the EU had clearly already started in $2013(431,095$ applications compared to 335,290 in 2012), but the years 2015 and 2016 presented an unprecedented number of asylum applications, with the peak in 2015 (1,322,845 applications). ${ }^{1}$ In 2017, the number of applications dropped again. Most of the applicants were from Syria and Iraq. The increased migration flow towards Europe was a result of more long-term problems in the source regions - mainly the rise of ISIS, but also changing environmental conditions combined with relatively poor economic conditions ${ }^{2}$ (Ionesco et al. 2017; UNHCR 2014).

The period quickly became known as a "migration crisis" or "refugee crisis". The term was widely used in the media around Europe, despite being challenged by many scientists. Admittedly, it was definitely a crisis for the people fleeing their homes (see for instance Goodman et al. 2017). The term has influenced overall perception of migrants and migration in many countries and that is also the reason why we use the term in the present paper.

Currently, Czechia is among the EU countries with the worst attitudes towards migration, together with Hungary (Čermáková and Leontiyeva 2017). This is an important change compared to some years ago when public opinion on migration was more positive (for example Chaloupková and Šalamounová (2006) analysed the European Social Survey from 2002 where Czechia scored around the average of twenty European countries included). In particular, the attitude towards refugees changed dramatically between 2013 and 2015. In 2013, 77\% of Czechs were willing to accept people fleeing war and natural disasters. In 2015 , this number dropped to only $2 \%$ (Jelínková 2019). The attitudes towards people with different religion, namely Muslims, have also changed over last years (e.g. People in Need 2015). This switch is quite possibly linked to the negative tone of the Czech media when referring to migration and the mostly negative portrayal of migrants and migration by Czech political leaders. At the same time, there were important initiatives of solidarity in the period of the "migration crisis" - for example Czech volunteers working in the Balkans (Jelínková 2019).

In the paper, it is examined whether the change in attitudes towards immigration is reflected in the opinions of young Czechs. Two surveys, conducted

1 Numbers of applications are total for EU-28 (Eurostat Database).

2 Poor economic conditions are often interrelated with environmental conditions - desertification, for instance, has an impact on agricultural production. in 2011 and 2016 respectively, among Czechs aged between 14 and 19 were used. This age group is particularly interesting as adolescence is the time when attitudes are being formed, then staying fairly stable throughout the individual's life (Kudrnáč 2017). Adolescents' views can also be different from the views of adults - which is proved for example in People in Need (2015). At the same time, school attendance means young people at this age are usually exposed more to information about history, geography, etc. than adults out of school, and their factual knowledge of the world can therefore be somewhat better or more active and it can influence their world views (factual knowledge as determinant of attitudes was used for example by Strabac et al. 2014). As Kurdnáč (2017) argues, this age group is also understudied and therefore deserves more attention.

To assess the potential changes of young Czechs' attitudes towards migration, three main questions are discussed:

1. Were respondents' overall attitudes different in two surveys held before and after the "migration crisis"?

2. Were some specific aspects of respondents' attitudes different in two surveys held before and after the "migration crisis"?

3. What factors influenced respondents' attitudes?

The surveys were based on the concept of worldmindedness. The concept is used as a tool to test values of respondents, in particular if they are oriented towards own social/national group or towards the whole world (Sampson and Smith 1957).

\subsection{World-mindedness}

Measuring attitudes towards immigration is rather complicated as there are many factors influencing such attitudes and the perception might differ between the general process of immigration and immigrants themselves, or between different distinct groups of immigrants (Ceobanu and Escandell 2010; Čermáková and Leontiyeva 2017; Hasman and Divínová 2020; Chaloupková and Šalamounová 2006). Therefore, the present surveys used (for the assessment of attitudes internationally well-established) world-mindedness scale as a research tool, especially for its close relation to the migration related attitudes. The scale was primarily formulated by Sampson and Smith (1957) and further developed by other authors (e.g. Hett). More recent studies (Beneker et al. 2013) compiled the original scale with the one by Hett (Hett in Hanus et al. 2017) into a new questionnaire consisting of personal items and 20 statements divided into four different thematic dimensions: patriotism a human rights, economy and migration, education and learning, and culture and attitudes to others (each containing five statements). In this study, the statements from the dimensions of economy and migration and culture and attitudes to others (together 
with the personal items) were used to address the research questions.

\subsection{The "migration crisis" and Czechia}

Since the 1990s, Czechia has gradually transformed from a country of prevailing emigration to a net immigration country (Drbohlav 2011). There are multiple reasons behind this switch, mainly relative political stability and economic growth, supported by the membership in the EU. Nevertheless, the numbers of immigrants living in Czechia and their percentage of total population are still fairly modest in the European context (Czech Statistical Office 2019). We can observe a tendency towards growth in the number of immigrants, with only a slowdown due to the economic crisis in 2007 and 2008. At the end of the year 2016, there were 496,413 immigrants in Czechia, which makes $4.5 \%$ of the country's total population a fairly low percentage compared to Western European countries, such as Austria (14.4\%), Germany (10.5\%), United Kingdom (8.6\%) or France (6.6\%), albeit this share is still higher than that of Eastern European countries (1.2\% in Slovakia, 1.6\% in Hungary, $0.4 \%$ in Poland) (Czech Statistical Office 2017). If we focus on refugees, the Czech numbers are very low in the EU context. In 2016, there were only 2,972 people with international protection ${ }^{3}$ (Czech Statistical Office 2017), i.e. people who obtained asylum or subsidiary protection in past years. Starting in 2014, as the migration flow to Europe intensified, there was only a modest increase in the number of new applications compared to previous years $(1,478$ new applications in 2016 with only 450 people granted international protection).

As for the composition of new applicants for asylum protection in 2016, the picture is also quite different from other European countries. In the EU, the main countries of origin of asylum applicants were Syria, Afghanistan and Iraq (Eurostat). In Czechia, the media and many politicians have kept informing the public about influx of refugees from Syria (or Muslim migrants), but the most numerous group of new applicants were Ukrainians fleeing the ongoing conflict in the Eastern part of their country, followed by Iraqis, Cubans and then Syrians (Czech Statistical Office 2016).

Overall, Czechia had above-average experiences with immigration in the Eastern-European context in 2015 and it was influenced by the so called migration crisis in 2015 and 2016 much less than other countries, especially when compared to its neighbour Germany. Yet an atmosphere of fear or even panic has

3 International protection includes asylum and subsidiary protection. Subsidiary protection is a temporary status introduced to protect people in cases where it is likely that the situation in their country of origin will change. Asylum is more similar to a permanent residence permit. been created, persuading many inhabitants that there are masses of dangerous migrants from Africa and the Middle East who are coming to ruin the country (Jelínková 2019). The topic of immigration came to be considered one of the top issues faced by Czechia and the EU (Eurobarometer 2011 and 2016). The topic has been raised by some political actors, including the president, to the top place in public debate. The manner of such debates was often manipulative. As a result, questions about immigration have had a decisive influence on political elections in the last years (Jelínková 2019). This seems to make little sense: why would migration and refugees become such a hot topic in a state that experiences moderate levels of immigration and very low numbers or asylum applications?

To look at this closer, three theoretical approaches to the perception of migrants were used: two theories on the group level and one on the individual level.

\subsection{Perception of immigration}

There are different concepts of perception of immigration; some focus more on the individual level, some focus more on the group level. For the analysis, three concepts were chosen, of which one focuses on the individual level (contact theory) and two on the group level (group threat, labour market competition).

The group threat theory says that a dominant group feels threatened by a minority group and fear they might lose their power and limited resources in competition with another (actually or apparently) growing group of people. ${ }^{4}$ The sense of threat is then expressed via negative sentiment and speech against that competing group (Berg 2009; Kudrnáč 2017). The key here is the perception of threat even by individuals who are doing well, but who fear that their position might be undermined by the changing situation. Mostly, the threat is perceived as economic, but some authors include also other aspects such are norms and moral values that different groups hold and that can be then perceived as in threat (Borgonovi and Pokropek 2019). This explains why it makes sense to build on the group threat theory even in the case of students, who naturally may not be affected by perceived economic threat as much as adult population.

The labour market competition theory focuses more (but not exclusively) on individuals of lower socioeconomic status who are more likely to believe that members of another group, particularly incoming immigrants, might take their jobs and therefore cause their unemployment (Chaloupková and Šalamounová 2006). Berg (2009) also points to regional differences and the fact that more negative attitudes toward immigrants are most likely to be found in regions that

4 The literature shows that often it is more the imagined size of the competing group than the real size that creates the sense of danger (Pottie-Sherman and Wilkes 2017). 
are in a worse economic situation. The participants of the surveys presented in this paper were students and as such probably not active (or only to a limited extent) in the labour market. Nevertheless, the labour market competition is still relevant, mainly because young people are prone to adapt to their parents' opinions and views (Borgonovi and Pokropek 2019; Miklikowska 2017). Therefore, young people can adapt their parents' views on the labour market and immigrants as competitors. This issue was addressed by questions A1, A2 and A3 (see Table 1).

However, the interpersonal environment can help to lower anti-immigrant sentiments. The first and probably best known concept here is the contact theory (sometimes called the contact hypothesis or intergroup contact) (Allport 1954). The theory suggests that prejudice between groups decreases with more face-to-face interaction; simply put, if you meet a person from a different group face to face, you are able to see him or her as a normal human being, just like you (Allport 1954; Pettigrew and Tropp 2006; Berg 2009). The study of Miklikowska (2017) provides evidence that such intergroup contact may even lower prejudice young people adapt from their parents.

\section{Materials and methods}

The theoretical approaches mentioned above were the basis for the analysis of the attitudes towards immigration among Czechs aged 14 to 19 in 2011 and 2016, respectively. The study is based on two questionnaire surveys held in Czechia with the same set of questions. The participants were contacted via their lower (aged 11 to 15) and upper (15 to 19) secondary schools.

The questionnaire contained 10 statements and 9 personal questions (see Table 1). The respondents marked their agreement or disagreement with each statement using the Likert scale of six possible answers: strongly disagree, disagree, somewhat disagree, somewhat agree, agree, and strongly agree. The possible answers were assigned points from 1 (strongly disagree) to 6 (strongly agree). Four of the statements were reversed to control for possible automatic answering without understanding the content. In the analysis, the scores for these reversed statements (A3, A5, B4 and B5 in Table 1) were subsequently reversed to enable comparison of scores throughout the whole questionnaire.

From these variables, a score of openness (= more positive attitudes) to immigration was counted. The range of the score is from 10 to 60; students who showed least openness therefore scored 10, while those with maximum openness scored 60.

To see what is behind positive attitudes towards immigration, i.e. what things influence it, regression analyses were run. In the regression models, openness to immigration was the dependent variable and
Tab.1 Questionnaire - statements and personal information. A. Economics and migration

A1. People from my country have a moral obligation to share their wealth with the less fortunate people of the world.

A2. In the long run, my country will probably benefit from the fact that the world is becoming more interconnected.

A3. Immigrants should not be permitted to come into our country if they compete with our own workers. (Reversed)

A4. Our country should allow immigration even if it lowers our standard of living.

A5. Our country should not cooperate in any international trade agreements which attempt to improve world economic conditions at our expense. (Reversed)

B. Cultural diversity

B1. People in our country can learn something of values from all different cultures.

B2. I enjoy trying to understand people's behaviour in the context of their culture.

B3. I generally find it stimulating to spend an evening talking with people from another culture.

B4. I have very little in common with people in developing countries. (Reversed)

B5. Foreigners are particularly obnoxious because of their religious beliefs. (Reversed)

C. Personal questions

1. Age

2. Gender

3. I have visited another continent.

4. I have visited another country.

5. I have lived in a different country than that of my citizenship.

6. I plan a stay abroad longer than 6 months before I turn 25 .

7. I am in touch with a person abroad (letters, e-mails, chat, etc.).

8. At least one of my close friends is an immigrant or a refugee.

9. I am interested in current affairs abroad.

the personal information (Table $1^{5}$ ), together with factors from factor analysis, were used as independent variables. In total, six different regression analyses were run: one for the total score of openness, three using factors created by factor analysis, and finally one apiece for the two years, to see whether there was any change in the influence of personal factors between 2011 and 2016. The first four models include a binary independent variable for the years to see whether there was any difference between the two surveys.

5 We excluded from the analysis the answer to the statement "I have visited another country." as almost all respondents marked 'Yes' (see Table 2), so it would have not brought any additional information. 
Tab. 2 Background information.

\begin{tabular}{|l|c|c|}
\hline Total number of questionnaires* & 2011 & 2016 \\
\hline Average age & 856 & 1,074 \\
\hline Female respondents (\%) & 16.4 & 15.6 \\
\hline $\begin{array}{l}\text { Respondents who have visited } \\
\text { another continent (\%) }\end{array}$ & 61.2 & 56.4 \\
\hline $\begin{array}{l}\text { Respondents who have visited } \\
\text { another country (\%) }\end{array}$ & 45.4 & 56.0 \\
\hline $\begin{array}{l}\text { Respondents who have lived in a different } \\
\text { country than that of their citizenship (\%) }\end{array}$ & 10.3 & 12.9 \\
\hline $\begin{array}{l}\text { Respondents who plan a stay abroad longer } \\
\text { than 6 months before turning 25 (\%) }\end{array}$ & 56.2 & 59.2 \\
\hline $\begin{array}{l}\text { Respondents who are in touch with a person } \\
\text { abroad (letters, e-mails, chat, etc.) (\%) }\end{array}$ & 54.3 & 54.7 \\
\hline $\begin{array}{l}\text { Respondents who have at least one close } \\
\text { friend who is an immigrant or a refugee (\%) }\end{array}$ & 61.8 & 65.0 \\
\hline $\begin{array}{l}\text { Respondents who are interested in current } \\
\text { affairs abroad (\%) }\end{array}$ & 97.7 & 88.5 \\
\hline
\end{tabular}

* We included only questionnaires with all questions filled in.

\subsection{Sample}

The respondents were students aged between 14 and 19 . The surveys were conducted in cooperation with their schools. The schools were contacted primarily through geography teachers cooperating with Charles University's Faculty of Science. ${ }^{6}$ The selection was therefore not random and so we do not use significance level in our models. As for the geographical dispersion of the sample, around $50 \%$ of questionnaires were collected in Prague and the rest in other locations in Czechia, including smaller towns. Most schools were grammar schools, which are schools for talented students - a fact that might influence the results (Hasman and Divínová 2020; Straková and Simonová 2013). Different towns were included in each of the two years (with only Prague included in both years), which might affect comparability of results between the two years. Thus, we cannot certainly assess, whether potential differences in results between both years are given by real change of attitudes caused, for instance, by the "migration crisis", or whether they are rather given by different sample.

For the analysis, only questionnaires with all questions completed were included - in 2011 this was $88.4 \%$, in $201689.5 \%$ of all questionnaires collected. Despite different schools being included from

6 The research sample was recruited in accordance with the ethical recommendations for the research with non-adult participants. Data collection took place at schools during geography lessons. The research was approved by the participating school management having general approval to such activities from the parents of students. Schools without such approval were eliminated. However, most of the schools asked data collectors to anonymize results (or not to collect detailed information about their students). Therefore, the personal questions were reduced. one survey to the next, the basic characteristics of the students were similar (Table 2). The exception is the number of students who had visited another continent, which rose between 2011 and 2017 by $10.6 \%$. The second change occurred in the question on students' interest in current affairs abroad, which dropped by $9.2 \%$. Nevertheless, even in 2016 more than $88 \%$ of the students were interested in foreign affairs - a fairly high number. A possible explanation may be a change of the type of media coverage of world affairs including many quite emotional and sensational contributions by the Czech media during the "migration crisis" (Jelínková 2019) but the available data does not allow to state a clear causality.

\section{Results}

Looking at overall results for both years, clear similarities can be found. The overall scores of openness did not differ much between the 2011 and 2016 samples (Table 3). The inner distribution of the samples was controlled to find whether the latter sample was more polarised than the former one. As shown in Table 4,

Tab. 3 Openness to immigration in the years 2011 and 2016 (scores from 10 to 60).

\begin{tabular}{|l|c|c|}
\hline Minimum & $\mathbf{2 0 1 1}$ & $\mathbf{2 0 1 6}$ \\
\hline Maximum & 13 & 10 \\
\hline Mean & 54 & 59 \\
\hline Standard deviation & 37.68 & 37.55 \\
\hline
\end{tabular}

Tab. 4 Factor Analysis Results

\begin{tabular}{|l|c|c|c|}
\hline $\begin{array}{l}\text { Factor number } \\
\text { standards of living }\end{array}$ & 1 & 2 & 3 \\
\hline $\begin{array}{l}\text { A3 - Immigrant workers are } \\
\text { allowed (Reversed) }\end{array}$ & 0.721 & & \\
\hline B5 - Religion (Reversed) & 0.460 & 0.420 & \\
\hline $\begin{array}{l}\text { A1 - Moral obligation to share } \\
\text { own wealth }\end{array}$ & 0.459 & & \\
\hline $\begin{array}{l}\text { B2 - Enjoying understanding } \\
\text { others' behaviour }\end{array}$ & & 0.710 & 0.682 \\
\hline $\begin{array}{l}\text { B3 - Talking to people from } \\
\text { different cultures }\end{array}$ & -0.323 & 0.536 & 0.319 \\
\hline $\begin{array}{l}\text { B1 - Learning from different } \\
\text { cultures }\end{array}$ & 0.345 & 0.447 & 0.560 \\
\hline $\begin{array}{l}\text { A2 - Benefit from the world's } \\
\text { interconnectedness }\end{array}$ & & & \\
\hline $\begin{array}{l}\text { A5 - International trade } \\
\text { agreements (reversed) }\end{array}$ & & & \\
\hline B4 - A lot in common & & & \\
\hline
\end{tabular}

Note: Table shows correlation coefficients between original statements and new derived factors. Values $<0.3$ have been suppressed. The rotation varimax was used. 
Tab. 5 Results for all ten statements and factors.

\begin{tabular}{|c|c|c|c|c|}
\hline \multirow{2}{*}{ Variable/Factor } & \multicolumn{2}{|c|}{2011} & \multicolumn{2}{|c|}{2016} \\
\hline & Mean & Standard deviation & Mean & Standard deviation \\
\hline A1 - Moral obligation to share own wealth & 2.91 & 1.248 & 2.96 & 1.240 \\
\hline A2 - Benefit from the world's interconnectedness & 3.87 & 1.063 & 3.81 & 1.083 \\
\hline A3 - Immigrant workers are allowed (Reversed) & 3.58 & 1.400 & 3.49 & 1.521 \\
\hline A4 - Immigration despite lower standards of living & 2.48 & 1.146 & 2.49 & 1.293 \\
\hline A5 - International trade agreements (Reversed) & 3.67 & 1.291 & 3.74 & 1.321 \\
\hline B1 - Learning from different cultures & 4.37 & 1.097 & 4.48 & 1.113 \\
\hline B2 - Enjoying understanding others' behaviour & 4.52 & 1.236 & 4.49 & 1.301 \\
\hline B3 - Talking to people from different cultures & 4.16 & 1.298 & 4.15 & 1.312 \\
\hline B4 - A lot in common & 3.34 & 1.315 & 3.49 & 1.242 \\
\hline B5 - Religion (Reversed) & 4.77 & 1.317 & 4.46 & 1.457 \\
\hline Factor 1 & 13.74 & 3.238 & 13.39 & 3.759 \\
\hline Factor 2 & 16.91 & 2.856 & 16.93 & 3.057 \\
\hline Factor 3 & 7.02 & 1.953 & 7.22 & 1.922 \\
\hline
\end{tabular}

Note: The reversed statements were recalculated in order to make them comparable with the other statements. In all cases, higher values mean higher openness.

standard deviation in 2016 was larger by almost $10 \%$, which could be a sign of higher polarisation as the mean was almost the same in both years.

The responses to the individual statements were also very similar in both years. A detailed summary of the responses is presented in Table 5. The table shows the means for all ten statements; the higher the mean is the more positive attitudes towards migration are. At first sight, the responses for all ten answers are very similar in both years. There is also a clear division between the answers for the statements on economy and migration (A1 to A5) and for those on cultural diversity (B1 to B5). This seems logical in that it might be natural to be more open to different cultures but careful about economic issues. Principal component analysis was run to examine in which statements our respondents answered similarly. Results confirmed that the division into two components is not straightforward and instead three factors (based on Eigenvalue larger than 1) should be extracted (Table 4). All three factors include both A and B statements. The subsequent closer examination of the three factors brought some logical explanation for this.

FACTOR 1: A1, A3, A4, B5. Statement B5 is "Foreigners are particularly obnoxious because of their religious beliefs." (Reversed). Thinking of media work on migration and some parts of public discourse, discussion of economic factors was commonly accompanied by discussion of migrants' religion (Islam in particular). Therefore, it is not surprising that these statements cluster together: respondents who view migrants as an economic threat might also see different religions as undesirable (and vice versa). The connection between these statements might be also related to their wording as they explicitly talk about foreigners and immigrants on the individual level rather than about general phenomena of migration, cultural diversity etc. This difference between attitudes towards immigration and attitudes towards immigrants (i.e. a general process vs. individual people) has been already documented in literature, for example in Pettigrew and Tropp (2006) and in Čermáková and Leontiyeva (2017).

FACTOR 2: B1, B2, B3, A2.7 Statement A2 is "In the long run, my country will probably benefit from the fact that the world is becoming more interconnected." This was included with the statements on economy and migration, but it does not mention economy directly - therefore it might be that respondents interpreted the statement in a wider sense and see other, non-economic, benefits of global interconnectedness. In that case, it makes sense that it is in the same component as statements on cultural diversity rather than statements on the economy. All the statements in this group point to benefits related to global issues and different cultures (see Table 1).

FACTOR 3: A5, B4. In the third component, the link might not be that clear, but we can see behind it an idea of not sharing with people in different countries because we have very little in common.

These three factors were used in the second set of regression models (see below) to see what personal characteristics influence the outcomes of these factors.

7 Table 4 shows that Factor 2 loadings of Statement B5 are nearly similar to those for Factor 1, so we also tried to include Statement B5 in Factor 2. Results of following regression analysis were, however, very similar regardless of B5 being or not being included in Factor 2. 


\subsection{What factors influence students' attitudes?}

To answer the research questions, six different regression analyses were run. Model 1 was built for the whole dataset and its aim was to investigate a general pattern of factors influencing students' attitudes. In Models 2-4, we examined factor scores, obtained from the factor analysis above, individually. The last two models, Model 5 and Model 6, were run to examine the two survey years (2011 and 2016) separately to examine whether the overall pattern differed between the two surveys. The first four models included a binary independent variable for the years to see whether there was any influence in the time change. These six models enabled us to observe the patterns in data more closely and to avoid hasty conclusions that could be reached if only the overall scores (shown in Table 5) were discussed.

Tab. 6 Model 1: Determinants of students' attitudes.

\begin{tabular}{|l|c|}
\cline { 2 - 2 } Dependent variable & $\begin{array}{c}\text { Openness to migration } \\
\text { and cultural diversity }\end{array}$ \\
\hline$R^{2}(\%)$ & 10.7 \\
\hline Independent variables & $\begin{array}{c}\text { Standardised regression } \\
\text { coefficients }\end{array}$ \\
\hline 2016 & 0.052 \\
\hline Age & 0.040 \\
\hline Female & 0.188 \\
\hline Visited another continent. & -0.014 \\
\hline Lived in a different country than that \\
of their citizenship.
\end{tabular}

In this model (described in Table 6), three variables stand out as most influential for the openness of the respondents: gender, previous experience with living in a different country and following current affairs abroad. The strongest role is that of gender female respondents were more likely to score higher openness, i.e. more positive attitudes, to migration and cultural diversity. Apart from gender, a somewhat important role of interest in current affairs abroad can be observed. Other factors with some effect on the scores are: (1) respondent lived in a different country, (2) respondent plans a longer stay abroad, and (3) respondent has a close friend who is an immigrant. In all cases, the influence was positive, e.g. respondents who lived in a different country had more open attitudes. On the other hand, the difference between 2011 and 2016 is very limited. This model points to the contact and social network theories, as living abroad and being interested in current international affairs means respondents are more likely to be in an environment where other people migrate temporarily or permanently abroad. Therefore, their anti-immigrant sentiments may be lower as they have either experienced a migrant-like situation themselves or know other people who have, and they are also more likely to have people from different countries among their friends.

In Models 2, 3, and 4, we used the results of the factor analysis (see above) and counted the points for the answers included in each factor (e.g. Factor 1 was counted by adding up the answers to statements A1, A3, A4 and B5). Table 7 shows that the independent variables have different impact on the three factors. As described above, Factor 1 includes statements that explicitly talk about individual migrants and therefore can obtain different answers than the statements on migration as a general phenomenon. The strongest

Tab. 7 Models 2, 3, and 4: Factor analysis.

\begin{tabular}{|l|c|c|c|}
\hline Dependent variable & Factor 1 & Factor 2 & Factor 3 \\
\cline { 2 - 4 } Model & 2 & 3 & 4 \\
\hline Statements included & A1+A3+A4+B5 & B1+B2+B3+A2 & A5+B4 \\
\hline$R^{2}(\%)$ & 6.3 & 11.8 & 1.4 \\
\hline Independent variables & \multicolumn{2}{|c|}{ Standardised regression coefficients } \\
\hline 2016 & -0.016 & 0.093 & 0.050 \\
\hline Age & 0.014 & 0.081 & -0.023 \\
\hline Gender & 0.154 & 0.167 & 0.047 \\
\hline Visited another continent. & -0.009 & -0.006 & -0.018 \\
\hline Lived in a different country than that of my citizenship. & 0.112 & 0.031 & 0.075 \\
\hline Plans a stay abroad longer than 6 months before the age of 25. & 0.048 & 0.125 & 0.004 \\
\hline In touch with a person abroad. & 0.001 & 0.077 & 0.015 \\
\hline One of close friends is an immigrant. & 0.090 & 0.065 & 0.039 \\
\hline Interested in the current affairs abroad. & 0.085 & 0.181 & 0.012 \\
\hline
\end{tabular}


influences on this factor are gender, having lived in a different continent and having an immigrant among friends. Such results again point to the contact theory: having lived abroad provides one with personal experience of being a migrant and having immigrants as friends provides contact with individual migrants and their specific situations, and as a result, these respondents have more positive attitudes towards migrants as individuals.

Statements on cultural issues and interconnectedness of the world are clustered in Factor 2. Gender plays an important role again, together with planning a stay abroad and following the news. This might be because people who think more outside the borders of their own state appreciate other cultures and are interested in them. Consequently, they are also interested in current affairs abroad and plan to stay abroad for some time. The connection between these issues seems logical, though the causality might be blurred.

Factor 3 includes two statements that are loosely connected through economic development of specific countries. As the connection is rather loose, the regression coefficients do not show any particular variable that would influence the outcomes of this factor.

Tab. 8 Models 5 and 6: Differences in attitudes' determinants between 2011 and 2016 .

\begin{tabular}{|l|c|c|}
\hline \multirow{2}{*}{ Dependent variable } & \multicolumn{2}{c|}{$\begin{array}{c}\text { Openness to migration } \\
\text { and cultural diversity }\end{array}$} \\
\hline Model & 5 & 6 \\
\hline Year & 2011 & 2016 \\
\hline $\mathbf{R}^{2}$ & 0.093 & 0.121 \\
\hline Independent variables & Standardised regression \\
\hline Gender & \multicolumn{2}{c|}{ coefficients } \\
\hline Age & 0.204 & 0.174 \\
\hline Visited another continent. & 0.011 & 0.055 \\
\hline $\begin{array}{l}\text { Lived in a different country than } \\
\text { that of my citizenship. }\end{array}$ & -0.026 & -0.005 \\
\hline $\begin{array}{l}\text { Plans a stay abroad longer than } \\
6 \text { months before the age of 25. }\end{array}$ & 0.116 & 0.097 \\
\hline In touch with a person abroad. & 0.084 & 0.097 \\
\hline One of my close friends is an immigrant. & 0.068 & 0.117 \\
\hline Interested in the current affairs abroad. & 0.130 & 0.137 \\
\hline
\end{tabular}

Models 5 and 6 are presented in Table 8 and show results for the two years of the survey separately. This step was aimed at revealing particular changes in the effects of particular determinants between the two surveys. Looking more closely at the results of Models 5 and 6, it can be observed that the role of gender was particularly high in both years, with female respondents demonstrating more positive attitudes. The differences in the regression coefficients are quite small, with the one exception of having an immigrant or a refugee among friends. This could be related to the extensive media coverage, whose depiction of immigration was quite scandalously biased, which may have made it hard for respondents to find their own position on the topic. Therefore, personally knowing an immigrant could prove to be the key to being more open to migration despite all the negative messages received from the media and politicians. If this is the case, it would be a proof of the contact theory (see also Hasman and Divínová 2020).

\section{Discussion}

In a situation where Czech immigration levels are still quite modest compared to Western Europe and where the country's economic situation has been good over the last years, the growing negative attitudes towards immigration may seem a little contradictory.

On the other hand, considering the theoretical concepts described above, the situation becomes clearer. Within the concept of group threat, there is a part of the population that can, despite the overall low unemployment levels, perceive immigrants as competitors in the labour market and in terms of values and norms, especially in some regions with higher unemployment levels and more remote regions that tend to be more homogeneous. In the sample, some of these tendencies can be observed. As indicated at Table 5, the scores for economic statements (A1 to A5) were on average lower in both years than the scores for cultural diversity (B1 to B5). This shows us that the respondents were more careful about sharing their own resources with immigrants - even in 2016 when the situation in labour market was already very good, with the unemployment level at 3.6\% (Czech Statistical Office). This would suggest that there is indeed a tendency to perceive immigration as an economic threat even among students who themselves do not participate in the labour market (or to a limited extent).

In support of the contact theory, we can observe the growing role of having an immigrant among one's friends: in 2016, it was more likely that respondents with immigrants among their friends were more open to immigration and cultural diversity. Therefore, having direct contact with an immigrant positively influenced their openness. In Models 2, 3, and 4, the influence of having an immigrant among one's friends proved to be more important for Factor 1 than for Factor 2, i.e. it was more important for a factor that mostly dealt with individual immigrants and their presence in Czechia. This further proves the importance of actually knowing some immigrants personally to having more positive attitudes towards immigrants/ immigration, in accordance with People in Need (2015), which also focused on students at secondary schools. Moreover, we can observe the importance of 
experience with living abroad - indirectly, this can be also considered a proof of the contact theory as it gives respondents experience of the migrant situation and meeting other migrants and people of different cultures, religions, etc. generally.

In all the models, it can be observed that the role of gender is important for the level of openness to immigration and cultural diversity, and that women are more likely to have more positive attitudes towards immigration. Such conclusions have already been shown in previous studies (for example Strabac et al. 2014; Hanus et al. 2017; Beneker et al. 2013), but on the other hand other studies did not prove the role of gender in attitudes towards immigration (Hasman and Divínová 2020; Chandler and Tsai 2001; Novotný and Polonský 2011), and others show only a partial or none tendency for men to have more negative attitudes towards immigrants or other types of minorities (Gorodzeisky and Semyonov 2009; Kudrnáč 2017).

Following current affairs and having lived in a different country proved to be generally the strongest predictors in our models. In the last model (for the year 2016) the growing importance for openness toward immigration of having an immigrant among friends was observed. Such growth of importance of this variable might be caused by the different context after the "migration crisis" - in the flood of media coverage, speeches and online posts on immigration, the existence of a friend who is an immigrant might have become a key determinant of respondents' attitude towards immigration. This is in accordance with the contact theory that highlights the importance of personal contact for a person's attitudes (Miklikowska 2017).

It is also worth noting that age did not have any influence on the openness of the respondents, though this might be an artefact of the fairly small age range of the respondents and their belonging among teenagers, i.e. same age group (similarly also Straková and Simonová 2013).

\subsection{Limitations of the survey}

Some limitation should be considered when dealing with the results of the survey. First of all, limits result from the method of contacting respondents - most of them were from grammar schools with a selective admission procedure, and at the same time, half of respondents came from Prague. These facts raise questions about the influence of the specific educational environment of grammar schools or distinctive social context of Prague compared to other parts of Czechia (Hasman and Divínová 2020).

Moreover, the described method of participants recruitment resulted in the fact that the research samples were not randomly selected and, therefore, were not representative for the whole population of young Czechs. Given that, it should be kept in mind that the study present results of two surveys (conducted in two different years) and indicate possible linkages between them. The exact influence of the media, time, education, etc. on the openness to migration should be confirmed by the subsequent studies using the initial finding of this study.

As for the questions themselves, there might be an issue concerning the specific relationship between Czechia and Slovakia (due to their common history) and the subsequent question of possible confusion as to whether a Slovak friend is an immigrant or not many people in Czechia do not perceive Slovaks as immigrants. However, this is likely to be different for younger people who are less used to being around Slovaks - therefore the issue may not apply to the sample. Nonetheless, it could be useful to include a question about who respondents perceive as an immigrant. Such perceptions can be based on knowledge of the actual situation (where immigrants in Czechia typically come from), personal experience (who are the immigrants the respondents personally know) or the media, fake news etc. (in which case the picture of an immigrant can be distorted far from reality). Such issues are discussed for example in Hasman and Divínová (2020), Strabac et al. (2014) and Hayes and Dowds (2006). Both of the latter two papers also discuss the question of who the respondents actually think of when thinking of an immigrant, but such an issue is difficult to handle in a survey - interviews would probably be more appropriate to go into such details.

Another issue could be posed by question five, "I have lived in a different country than that of my citizenship.", primarily for respondents who have nonCzech citizenship (including dual citizenship) yet live in Czechia. The use of citizenship as a defining category is probably not ideal, ${ }^{8}$ especially with young people for whom all the consequences and legal issues related to citizenship might not be clear. However, the number of immigrants at Czech secondary schools is still modest, so this problem should not cause problems for the overall interpretation of the results.

The last issue to be considered is the reliability of the answers themselves - as in other surveys, respondents may reply as they think is expected rather than as they actually think. This might be particularly true of the age group 14-19, who may tend to reply in accordance to the overall climate at school or in class rather than expressing their real opinions. Conversely, in this age group, we may expect cases of rebellion, i.e. respondents marking more extreme opinions on purpose (Kudrnáč 2017).

8 Citizenship is the main distinguishing characteristic used by the Czech Statistical Office and other state institutions, which influences how migration is studied in Czechia. 


\section{Conclusion}

In this paper, attitudes towards immigration and immigrants before and after the "migration crisis" among Czech youth were examined. The research was based on two surveys, conducted in 2011 and 2016 respectively. The results show that there was not a tremendous difference in the attitudes. Nevertheless, looking closely at the results, two main differences can be observed.

First, higher polarisation of answers in 2016 than in 2011, i.e. in 2016 there were more answers at each end of the spectrum rather than in the middle.

Second, factors influencing answers, mainly in the statement on having an immigrant among one's close friends. It seems that in the extensive and often emotional media coverage of the "migration crisis", having an immigrant as a friend became even more decisive, demonstrating the validity of the contact theory (Miklikowska 2017). The contribution of such finding is the fact that in the present study, the theory was tested in the context of a Central European post-socialist country, i.e. in a different context than most studies working with the contact theory. Therefore, it can be said that providing evidence for the contact theory in such a different context moves its validity even further and makes it more robust.

The group threat theory was not persuasively supported by our data. However, there were some indications in this direction, mainly the fact that the scores on economic statements were consistently lower than those on more general cultural issues. The respondents seemed to be more careful about the economy and sharing their own wealth while being comparatively more open towards cultural diversity. The findings of this study can contribute not only to the knowledge in the field of attitudes towards migration but (considering the "school age" of participants) also to the development of attitudes towards migration at lower and upper secondary schools - in terms of developing and planning the curriculum in such a way that it would enhance students' attitudes. Especially, the paper points out the need to pay attention to the development of students' attitudes (in parallel to their knowledge and skills) and can help teachers to advocate the implementation of such development into the school curriculum. Moreover, the paper provides an easy-to-replicate tool for assessment of attitudes that can be used in classes (of geography). Additionally, the paper results serve as a comparative framework for such in-class experiments. Finally, teachers could benefit from the knowledge of the factors influencing the openness of young people towards migration (or influencing the general development of attitudes) when planning, performing and assessing educational activities - they can highlight factors supporting the openness (e.g. related to the contact theory) and/or be aware of factors that hamper the development of such attitudes (e.g. factors related to the group theory).

\section{Acknowledgements}

This study was supported by Charles University under Charles University Research Centre program no. UNCE/HUM/024 and program no. UNCE/HUM /018.

\section{References}

Allport, G. W. (1954): The Nature of Prejudice. Oxford: Addison-Wesley.

Béneker, T., Sirpa, T., Uphues, R., van der Vaart, R. (2013): Young People's World-Mindedness and the Global Dimension in their Geography Education: A Comparative Study of Upper Secondary School Students' Ideas in Finland, Germany and the Netherlands. International Research in Geographical and Environmental Education 22(4), 322-336, https://doi.org/10.1080/10382046 .2013 .826544 .

Berg, J. A. (2009): White Public Opinion toward Undocumented Immigrants: Threat and Interpersonal Environment. Sociological Perspectives 52(1), 39-58. https://doi.org/10.1525/sop.2009.52.1.39.

Borgonovi, F., Prokopek, A. (2019): Education and Attitudes towards Migration in a Cross Country Perspective. Frontiers in Psychology, 1-17, https://doi.org/10.3389 /fpsyg.2019.02224.

Bořil, V. (2018): Politická makrogeografie současného veřejného mínění o imigraci a uprchlické krizi v Evropské unii: víceúrovňové analýzy. Master Thesis, Charles University.

Ceobanu, A. M., Escandell, X. (2010): Comparative Analyses of Public Attitudes Toward Immigrants and Immigration Using Multinational Survey Data: A Review of Theories and Research. Annual Review of Sociology 36, 309-328, https://doi.org/10.1146/annurev.soc.012809.102651.

Chaloupková, J., Šalamounová, P. (2006): Postoje k imigrantům a dopadům migrace v evropských zemích. Sociologický časopis/Czech Sociological Review 42(1), 57-80.

Chandler, C. R., Tsai, Y. (2001): Social Factors influencing Immigration Attitudes: An Analysis of Data from the General Social Survey. The Social Science Journal 38(2), 177-188, https://doi.org/10.1016/S0362-3319 (01)00106-9.

Czech Statistical Office: Online Database (accessed April 14, 2019).

Čermáková, D., Leontiyeva, Y. (2017): 'I do not Mind Immigrants; it is Immigration that Bothers me.' The Inconsistency of Immigration Attitudes in Europe. Geografie 122(4), 500-525, https://doi.org/10.37040 /geografie2017122040500.

Dalakoglou, D. (2016): Europe's Last Frontier: The Spatialities of the Refugee Crisis. City 20(2), 180-185, https://doi.org/10.1080/13604813.2016.1170467.

de Haas, H., Czaika, M., Flahaux, M. L., Mahendra, E., Natter, K., Vezzoli, S., Villares-Varela, M. (2018): International Migration: Trends, Determinants and 
Policy Effects. IMIn Working Paper Series, 142. International Migration Institute Network.

Drbohlav, D. (ed.) (2011): Migrace a (i)migranti v Česku - Kdo jsme, odkud přicházíme, kam jdeme? Prague: Sociologické nakladatelství SLON.

Eurostat: Online Database (accessed April 13, 2019).

Foreigners in the Czech Republic 2016. Prague: Czech Statistical Office.

Foreigners in the Czech Republic 2017. Prague: Czech Statistical Office.

Foreigners in the Czech Republic 2018. Prague: Czech Statistical Office.

Foreigners in the Czech Republic 2019. Prague: Czech Statistical Office.

Goodman, S., Sirryeh, A., McMahon, S. (2017): The Evolving (Re)Categorisations of Refugees Throughout the "Refugee/Migrant Crisis". Journal of Community and Applied Social Psychology 27(2), 105-11, https://doi .org/10.1002/casp.2302.

Gorodzeisky, A., Semyonov, M. (2009): Terms of Exclusion: Public Views towards Admission and Allocation of Rights to Immigrants in European Countries. Ethnic and Racial Studies 32(3), 401-423, https://doi.org /10.1080/01419870802245851.

Hanus, M., Rezníčková, D., Marada, M., Benéker, T. (2017): Globální myšlení žáků: srovnání vybraných evropských zemí. Geografie 122(3), 359-381, https://doi.org /10.1080/01419870802245851.

Hasman, J., Divínová, P. (2020): Regionální rozdíly ve vnímání mezinárodní migrace studenty středních škol a jejich podmiňující faktory. Sociologický časopis. In print.

Hasman, J., Novotný, J. (2017): Kdo, odkud, kam a s kým: prostorová př́ibuznost migračních skupin na globální i lokální úrovni. Prague: Nadace Nadání Josefa, Marie a Zdeňky Hlávkových.

Hayes, B. C., Dowds, L. (2006): Social Contact, Cultural Marginality or Economic Self-Interest? Attitudes towards Immigrants in Northern Ireland. Journal of Ethnic and Migration Studies, 32(3), 455-476, https://doi.org /10.1080/13691830600554890.

Ionesco, D., Mokhnacheva, D., Gemenne, F. (2017): The Atlas of Environmental Migration. Abingdon: Routledge.

Jelínková, M., (2019): A Refugee Crisis without Refugees: Policy and Media Discourse on Refugees in the Czech Republic and its Implications. Central European Journal of Politics 13(1), 33-45, https://doi.org/10.2478/cejpp -2019-0003.

Kudrnáč, A. (2017): Gender Differences among Czech Youth in Prejudice towards Minorities. Journal of Youth Studies 20(5), 583-604, https://doi.org/10.1080/13676261 .2016 .1254166 .
Menéndez, A. J. (2016): The Refugee Crisis: Between Human Tragedy and Symptom of the Structural Crisis of European Integration. European Law Journal 22(4), 388-416, https://doi.org/10.1111/eulj.12192.

Merryfield, M.M., Lo, T-Y., PO, S. C., Masataka, K. (2008): Worldmindedness: Taking Off the Blinders. Journal of Curriculum and Instruction 2(1), 6-20, http://www.joci .ecu.edu/index.php/JoCI/article/view/9.

Miklikowska, M. (2017): Development of Anti-Immigrant Attitudes in Adolescence: The Role of Parents, Peers, Intergroup Friendships, and Empathy. British Journal of Psychology 108, 626-648, https://doi.org/10.1111 /bjop.12236.

Novotný, J., Polonský, F. (2011): The Level of Knowledge about Islam and Perception of Islam among Czech and Slovak University Students: Does Ignorance Determine Subjective Attitudes? Sociológia 43(6), 674-696.

Pettigrew, T. F., Tropp, L. R. (2006): A Meta-Analytic Test of Intergroup Contact Theory. Journal of Personality and Social Psychology 90(5), 751-783, https://doi.org /10.1037/0022-3514.90.5.751.

Pottie-Sherman, Y., Wilkes, R. (2017): Does Size Really Matter? On the Relationship between Immigrant Group Size and Anti-Immigrant Prejudice. International Migration Review 51(1), 218-250, https://doi.org /10.1111/imre.12191.

People in Need (2015): Rovnost a menšiny očima středoškoláků. Prague: Člověk v tísni/People in Need.

Sampson, D. L., Smith, H. P. (1957): A Scale to Measure World-Minded Attitudes. Journal of Social Psychology 45, 99-106, https://doi.org/10.1080/00224545.1957 .9714290 .

Strabac, Z., Aalberg, T., Valenta, M. (2014): Attitudes towards Muslim Immigrants: Evidence from Survey Experiments across Four Countries. Journal of Ethnic and Migration Studies 40(1), 100-118, https://doi.org /10.1080/1369183X.2013.831542.

Straková, J., Simonová, J. (2013): Vliv navštěvované střední školy na občanské postoje středoškoláků v ČR. Orbis Scholae 27(3), 27-47, https://doi.org/10.14712 /23363177.2015.12.

UNHCR (2014): Sharp increase in Iraqi refugees fleeing ISIS into Jordan and Turkey, https://www.unhcr.org/news /briefing/2014/9/54214cfe9/sharp-increase-iraqi -refugees-fleeing-isis-jordan-turkey.html?query=ISIS, accessed March 9, 2019.

Visser, P. S., Mirabile, R. R. (2004): The Impact of Social Network Composition on Individual-Level Attitude Strength." Journal of Personality and Social Psychology, 87(6), 779-795, https://doi.org/10.1037 /0022-3514.87.6.779.

World Bank: Online Database (accessed March 9, 2019). 